\title{
CHANGES IN THE QUALITY OF OLD APPLE CULTIVARS AFTER FREEZE-DRYING
}

\author{
- Research paper -
}

\author{
Fryderyk SIKORA*, Sabina LACHOWICZ**, Ireneusz KAPUSTA ${ }^{* * *}$, Marek \\ DYLAWERSKI $^{* * * *}$, Wojciech ZYSKA ${ }^{* * * * *}$, Ireneusz OCHMIAN ${ }^{1 *}$ \\ * Department of Horticulture, West Pomeranian University of Technology Szczecin, Stowackiego 17 \\ Street, 71-434 Szczecin, Poland; Ireneusz Ochmian; ORCID 0000-0002-3606-1927; Fryderyk \\ SIKORA; fryderyk.sikora@zut.edu.pl, ORCID 0000-0002-3384-6462 \\ ** Department of Fermentation and Cereals Technology, Wroclaw University of Environmental and \\ Life Sciences, Chetmońskiego 37 Street, 51-630 Wrocław, Poland; Sabina Lachowicz; \\ sabina.lachowicz@upwr.edu.pl,ORCID0000-0001-6182-0211 \\ *** Department of Food Technology and Human Nutrition, Rzeszów University, Zelwerowicza 4 \\ Street, 35-601 Rzeszów, Poland; ikapusta@univ.rzeszow.pl \\ *****Woliński National Park, Niepodległości 3a Street; 72-500 Międzyzdroje, Poland; \\ m.dylawerski@wolinpn.pl \\ ****** Przyroda Wiesława Zyska, Noakowskiego 19/3-4 Street; 70-380 Szczecin, Poland; \\ natura@poczta.onet.pl
}

\begin{abstract}
There are several thousand different cultivars of apple trees but only a limited number are cultivated on an industrial scale. Old cultivars can be useful, for example, in the processing industry due to their different composition. In many cases, they have higher organic acid content. The content of mineral components, colour, and polyphenols in the fruit of 7 old apple tree cultivars, growing in the Wolinski National Park, was studied. The changes that occurred in the fruit after freeze-drying were also evaluated. The trees from which the fruit was picked for analysis, despite the lack of chemical protection, were fruiting and the apples had only a few symptoms of damage caused by pests or diseases. The fruit was characterised by a high soluble solids content (14.4-16.4\%), in which sugars and especially fructose dominated. The number of organic acids varied greatly and ranged from 0.27 (Oberlander Himbeerapfel) g to $1.07 \mathrm{~g} / 100 \mathrm{~g}$ (Winter Goldparmane). The content of polyphenols in fresh apples ranged from $186 \mathrm{mg}$ (Horneburger Pfannkuchenapfel) to 354 $\mathrm{mg} / 100 \mathrm{~g}$ (Winter Goldparmane) and increased after freeze-drying from $666 \mathrm{mg}$ (Weisser Winterkalvill) to $1486 \mathrm{mg} / 100$ $\mathrm{g}$ (Winter Goldparmane). The dominant group of polyphenolic compounds was phenolic acid. The freeze-drying process caused unfavourable changes in the colour of the pulp. The fruits of Oberlander Himbeerapfel cultivar were most susceptible to these changes. However, the least darkened fruit of Horneburger Pfannkuchenapfel.
\end{abstract}

Key words: polyphenolic compounds, colour changes, pathogens contamination

\section{INTRODUCTION}

There are over a dozen thousand different apple trees cultivars in the world. But nowadays, mainly those with the highest every year yields and are more resistant to diseases are grown on an industrial scale (Kellerhals et al., 2012). These changes have been taking place since the second half of the 20th century. These trees are characterised by the fruit of high weight; however, the composition of these apples may turn out to be poorer in components

Received: 08.06.2020.

Accepted in revised form: 12.10 .2020 valuable for people than the old cultivars fruit (Van Treuren et al., 2010). Fruit trees were planted on public roads, between fields, and on private properties. They provided fruit and were an esthetic element, especially when they were deliberately formed into different geometric forms. They also shaped the landscape and protected against sun, wind, and snow.

The research results indicate that older apple cultivars can find many different ways of use in the processing industry. They can compete with the currently leading cultivars and even be an

${ }^{1}$ Corresponding author. E-Mail address: iochmian@zut.edu.pl 
alternative for them (Oszmiański et al., 2018). The locality of the appearance of such cultivars does not have to be an obstacle to industrial use. Perhaps there are cultivars in every region that deserve the processing industry's attention.

Valuable micro and macro components, but also polyphenols contained in apples can be used in many ways (Le Bourvellec et al., 2011). Moreover, in old apple cultivars, richer aroma, taste, sensory and nutritional values were found in comparison to modern ones (Oszmiański et al., 2018; Donno et al., 2012; Ciesa et al., 2015). Local alcohol producers who want to be distinguished may produce cider or tinctures with pro-healthy properties.

Old cultivars apples are also characterised by higher acidity, which is required by the processing industry. They can also be snacks in the form of crispy, fat-free chips without preservatives or flavour enhancers. In contrast to other snacks they are low in calories, rich in fibre and gluten-free (Janowicz et al., 2012; Konopacka, 2003). However, the genes of forgotten apple trees cultivars can be used to create new cultivars, which may be more resistant to diseases. Besides, genetic admixture can be introduced in orchards to reduce the monocultures' susceptibility to harmful factors. Older cultivars are characterised by greater resistance to negative biotic factors such as fungi or insects and abiotic such as climate change (Tetera, 2003). Existing cultivars should be preserved in order not to lose them completely. They are also part of cultural heritage.

Forests and national parks are a good place to look for research material. Many areas once inhabited by people have been planted with forests or naturally overgrown by plants. In places where fruit trees used to be grown, they can still be found today.
They are usually neglected but still bear fruit. In western Poland there are many local cultivars of German origin, in the eastern part of the country, there are Russian cultivars. This is due to the history of Poland, which for a long time was under the foreign countries' influence, which can be seen even in plant cultivation in different regions (Poznański et al., 2014).

It is also worth remembering that each successive species is very valuable for biodiversity. Especially in times of climate change, it is important to remember to take care of it. There are changes in the range of species appearance therefore the greater is the diversity of plants, the greater is the probability of their survival (Poznański et al., 2014; Wypych, 2017). Moreover, fruits can be food for wild animals. Although we do not have as cold winters as some time ago, the issue of feeding the animals is still relevant. One of the hunting purposes is to reduce damage to the crops by keeping the animals in the forest with their feed (Czyżowski et al., 2017). Regardless of the weather, the larger and more varied is the feeding base, the better it is for the ecosystem.

During the afforestation or renovation of the postfelling area, foresters also plant biocenosis species. These are often fruit trees such as rowanberry, hawthorn, pear, or apple tree (Haze, 2012). It is worthwhile to plant valuable old cultivars trees if they are available.

This research aims to assess the quality and chemical composition of old apple cultivars and the possibility of their use in the food industry. Fruits are evaluated mainly as sources of bioactive substances. Changes in colour and content of polyphenols after freeze-drying are also studied.

island delta of the Świna River, a coastal strip of Baltic waters. Until 1996 the Park covered an area of 4691 ha, when the area of 1 nautical mile of the Baltic coastal waters, the archipelago of islands in the backward delta of the Swina River and the surrounding waters of the Szczecinski Bay were included in its borders. Since that moment the Wolinski National Park has become the first sea park in Poland. The current area of the Park is 10937 ha, including forest ecosystems occupying 4648.53 ha $(42.50 \%$ of the Park's area), water ecosystems 4681.41 ha $(42.80 \%)$, and non-forest terrestrial ecosystems 1607.46 ha $(14.70 \%)$. The total area of 498.72 ha ( $4.56 \%)$ is strictly protected.

Within the Park and in the neighboring areas one can find remains of strongholds and other places of 
historic settlements, which are both subject to scientific research and tourist attraction.

\section{Plant materials}

Fruits of 7 old apple cultivars: Weisser Winterkalvill, Oberlander Himbeerapfel, Winter Goldparmane, Landsberger Renette, Kaiser Wilhelm, Horneburger Pfannkuchenapfel, Altlander Pfannkuchenapfel were studied. Fruit samples were collected from trees growing in abandoned human settlements, which are currently located in the Wolin National Park.

\section{Chemical analysis \\ General fruits parameters}

The weight of fruits was measured with RADWAG WPX 4500 electronic scales (accuracy $0.01 \mathrm{~g}$ ). The content of soluble solids was defined with PAL-1 digital refractometer (Atago, Japan). Titration acidity was determined by titrating an aqueous extract of $0.1 \mathrm{~N} \mathrm{NaOH}$ homogenate to an endpoint with $\mathrm{pH} 8.1$ (measured with Elmetron CX-732 multimeter), according to the PN-90/A-75101/04 standard. The content of dry matter was determined according to the relevant Polish Standard (PN90/A-75101/03, 1990).

\section{Determination of colour}

The fruits pigments measurement was carried out using spectrophotometer CM-700d (Konica Minolta, Japan). Measurements were made in CIE $L^{*} a * b^{*}$ system (Chelpiński et al. 2019). Measurements were taken with the aperture diameter $3 \mathrm{~mm}$, through a $10^{\circ}$ observer type and D65 illuminant. The value of $+a^{*}$ indicates redness; $-a^{*}$ indicates greenness on the surface of fruits and the parameter $+b^{*}$ means yellow; $-b^{*}$ means blue. The value of parameter $L^{*}$ varies from 0 to 100 , from black to white respectively.

\section{Extraction procedure and identification of} phenolic compounds, sugars, and pectin

Fruit selected for analysis (three replicas of $100 \mathrm{~g}$ each) were stored frozen at $-65{ }^{\circ} \mathrm{C}$. Fruit lyophilisates were weighed in an amount of $5 \mathrm{mg}$ into 2-mL Eppendorf vials. Subsequently, $0.8 \mathrm{~mL}$ of the methanolic solution of phloroglucinol $(75 \mathrm{~g} / \mathrm{L})$ and ascorbic acid $(15 \mathrm{~g} / \mathrm{L})$ were added to samples.
After the addition of $0.4 \mathrm{~mL}$ of methanolic $\mathrm{HCl}(0.3$ $\mathrm{M})$, the vials were incubated for $30 \mathrm{~min}$ at $50{ }^{\circ} \mathrm{C}$ with continuous vortexing in a thermo shaker. The reaction was terminated by placing the vials in an ice bath, drawing $0.6 \mathrm{~mL}$ of the reaction medium and diluting with $1.0 \mathrm{~mL}$ of sodium acetate buffer $(0.2 \mathrm{M})$. The samples were centrifuged immediately at $20000 \mathrm{~g}$ for $10 \mathrm{~min}$ at $4{ }^{\circ} \mathrm{C}$. They were then prepared according to the recommendations of Oszmiański et al. (2018). Nitrates' content was measured with a RQflex 10 requantometer (Mijowska et al., 2016). Sugars were determined according to Polish Standards (PN-90/A-75101/07) and by the HPLC method. Pectins content was analysed according to the Morris method described by Pijanowski et al., (1973). Acidity was determined by titration of the aqueous extract with $0.1 \mathrm{~N} \mathrm{NaOH}$ to an end point with $\mathrm{pH} 8.1$ (Elmetron CX-732), according to the PN-90/A-75101/04 standard. All samples were assayed in triplicate.

\section{Freeze-drying(Lyophilizing) process}

Before the drying process, the fruit was pre-frozen at $-35{ }^{\circ} \mathrm{C}$ in approx. 2 hours. Immediately after this treatment, the berries were subjected to freezedrying. Was used for this purpose lyophilizer of Christ model Alpha 1-2 LD + settings:

1) primary drying was carried out at the temperature of $-56^{\circ} \mathrm{C}$, pressure $0.018 \mathrm{Mbar}$,

2) a final drying step carried out for the last 4 hours of drying temperature $-76^{\circ} \mathrm{C}$, the pressure of 0.001 Mbar.

Homogeneous powders from dried fruit were prepared in a closed laboratory mill to avoid hydration. Then the water content of the fruit was examined. Dry fruit according to PN-90/A75101/03 was determined in fresh and dried fruit.

\section{Statistical Analysis}

All statistical analyses were performed with Statistica 12.5 (StatSoft Polska, Cracow, Poland). Statistical significance of the differences between means was established by testing homogeneity of variance and normality of distribution followed by ANOVA with Tukey's post hoc test, significance was set at $\mathrm{p}<0.05$. The results are expressed as means. 


\section{RESULTS AND DISCUSSION}

\section{Quality of fresh fruit}

The high fruit weight is one of the main factors that make it attractive to consumers. The fruit resistance to various pathogens and pests is also important. The greater is the sensitivity to these factors, the more the yield decreases (Oszmiański et al., 2018). Apples usually weigh about $200 \mathrm{~g}$ and have a diameter of up to $80 \mathrm{~mm}$ (Ochmian, 2007). The highest average fruit weight is characteristic for the Landsberger Renette cultivar (305 g). However, on this cultivar symptoms of apple scab were found (Table 1). Additionally, traces were observed on the fruit after apple sawfly feeding. Large fruits, weighing $289 \mathrm{~g}$, were characteristic for Winter Goldparmane. Apple scab was also presented on them, in very small quantities. No pests were found. The cultivar with the lowest fruit weight average is Altlander Pfannkuchenapfel. However, as the only cultivar described, it was not infested by apple scab or settled by pests. However, it should be noted that none of the described cultivars has been protected against pathogens by chemical means for several decades. This demonstrates the high resistance of these cultivars to environmental conditions.

For processing, Winter Goldparmane can be most profitable due to its high fruit weight and low susceptibility to diseases and pests. The Landsberger Renette cultivar, which fruit was the largest, however, was most damaged by fungi and insects. Though, the chemical composition of the fruit proves its suitability for processing or taste. Today, consumers prefer sweeter cultivars with less organic acids. Breeding research is conducted in this direction. However, the industry is looking for other fruits with higher acidity. The answer to these expectations may be old cultivars, often only found locally (Mohanty et al., 2006).

The high soluble solids (extract) content is highly correlated with the fruit sugar content. However, it does not always indicate a high amount of sugars. Both groups of ingredients also influence the fruit dry matter content. The extract also contains other water-soluble substances, including organic acids. A large amount of sugar in the fruit is demanded due to the taste and fruit processing properties. The appropriate fruit acid content is equally important. Acids emphasise the apple taste, but especially determine the taste of the preserves.

Fruit with a low acid content is of little use to the processing industry. Dried apples or ciders will only be sweet, without a pronounced taste (Mohanty et al., 2006). The results indicate and confirm that apples consist mainly of water. This is an ingredient that we want to get rid of during drying while preserving the other ingredients. For health reasons, a higher proportion of glucose and a lower proportion of fructose and sucrose are preferred (Page et al., 2013). Kaiser Wilhelm cultivar was characterised by the highest soluble solids content $(14.4 \%)$, it also contained the most sugar 11.99 $\mathrm{g} / 100 \mathrm{~g}$ (Table 2).

Table 1. Fruit weight and contamination by pathogens of the tested old apple cultivars

\begin{tabular}{llll}
\hline Cultivar & Weight of fruit $(\mathrm{g})$ & Pathogeny infection & Insect damage \\
\hline Weisser Winterkalvill & $185 \mathrm{bc} *$ & Apple scab - very little & no \\
Oberlander Himbeerapfel & $169 \mathrm{ab}$ & Apple scab - little. Bitter pit & no \\
Winter Goldparmane & $289 \mathrm{~d}$ & Apple scab - very little & no \\
Landsberger Renette & $305 \mathrm{~d}$ & Apple scab - average & Apple sawfly \\
Kaiser Wilhelm & $203 \mathrm{c}$ & no & Codling moth \\
Horneburger Pfannkuchenapfel & $198 \mathrm{bc}$ & no & Codling moth \\
Altlander Pfannkuchenapfel & $149 \mathrm{a}$ & no & no
\end{tabular}

*Means followed by the same letter do not differ significantly at $\mathrm{P}=0.05$ according to Tukey test

Table 2. Acidity and sugar content of the tested fruit of old apple cultivars

\begin{tabular}{|c|c|c|c|c|c|c|c|c|}
\hline Cultivar & $\begin{array}{l}\text { Dry matter } \\
(\%)\end{array}$ & $\begin{array}{l}\text { Soluble } \\
\text { solids }\left(\mathrm{Bx}^{\circ}\right)\end{array}$ & $\begin{array}{l}\text { Fructose } \\
(\mathrm{g} / 100 \mathrm{~g})\end{array}$ & $\begin{array}{l}\text { Glucose } \\
(\mathrm{g} / 100 \mathrm{~g})\end{array}$ & $\begin{array}{l}\text { Sucrose } \\
(\mathrm{g} / 100 \mathrm{~g})\end{array}$ & $\begin{array}{l}\text { Total sugars } \\
(\mathrm{g} / 100 \mathrm{~g})\end{array}$ & $\begin{array}{l}\text { Total acids } \\
(\mathrm{g} / 100 \mathrm{~g})\end{array}$ & $\begin{array}{l}\text { Sugars/ } \\
\text { Acids }\end{array}$ \\
\hline Weisser Winterkalvill & $15.2 \mathrm{~b}$ & $13.7 \mathrm{c}$ & $6.12 \mathrm{~b}$ & $2.60 \mathrm{c}$ & $0.53 \mathrm{a}$ & $9.25 \mathrm{ab}$ & $0.91 \mathrm{c}$ & 10.2 \\
\hline Oberlander Himbeerapfel & $16.4 \mathrm{~d}$ & $14.7 \mathrm{~d}$ & $6.67 \mathrm{~cd}$ & $2.50 \mathrm{c}$ & $0.46 \mathrm{a}$ & $9.63 \mathrm{~b}$ & $0.27 \mathrm{a}$ & 35.7 \\
\hline Winter Goldparmane & $15.7 \mathrm{c}$ & $13.0 \mathrm{~b}$ & $8.52 \mathrm{e}$ & $2.11 \mathrm{ab}$ & $0.46 \mathrm{a}$ & $11.09 \mathrm{c}$ & $1.07 \mathrm{~d}$ & 10.4 \\
\hline Landsberger Renette & $15.5 \mathrm{bc}$ & $13.8 \mathrm{c}$ & $6.52 \mathrm{c}$ & $2.26 \mathrm{~b}$ & $2.29 \mathrm{c}$ & $11.07 \mathrm{c}$ & $0.94 \mathrm{c}$ & 11.8 \\
\hline Kaiser Wilhelm & $16.2 \mathrm{~d}$ & $14.4 \mathrm{~d}$ & $6.82 \mathrm{~d}$ & $2.45 \mathrm{c}$ & $2.72 \mathrm{e}$ & $11.99 \mathrm{c}$ & $0.59 \mathrm{~b}$ & 20.3 \\
\hline $\begin{array}{l}\text { Horneburger } \\
\text { Pfannkuchenapfel }\end{array}$ & $14.4 \mathrm{a}$ & $12.6 \mathrm{a}$ & $6.14 b$ & $2.09 \mathrm{a}$ & $0.64 \mathrm{~b}$ & $8.87 \mathrm{ab}$ & $0.93 \mathrm{c}$ & 9.5 \\
\hline $\begin{array}{l}\text { Altlander } \\
\text { Pfannkuchenapfel }\end{array}$ & $14.6 \mathrm{a}$ & $12.3 \mathrm{a}$ & $3.96 \mathrm{a}$ & $2.22 \mathrm{ab}$ & $2.41 \mathrm{~d}$ & $8.59 \mathrm{a}$ & $0.91 \mathrm{c}$ & 9.4 \\
\hline
\end{tabular}


At the same time, it was characterised by the highest sucrose content ( $2.72 \mathrm{~g})$, relatively high glucose content $(2.45 \mathrm{~g})$, and medium fructose content $(6.87 \mathrm{~g})$. On the other hand, Winter Goldparmane cultivar contained a relatively high amount of sugars $(11.09 \mathrm{~g})$ with relatively low soluble solids content (13.0\%).

Among the determined sugars, fructose $(8.52 \mathrm{~g})$ prevailed, which was the highest in comparison with other cultivars. However, very little sucrose $(0.46 \mathrm{~g})$ was found. In the fruits of this cultivar, the highest organic acids $(1.07 \mathrm{~g} / 100 \mathrm{~g})$ amount was also found. It was almost four times more than in the fruit of Oberlander Himbeerapfel cultivar $(0.27 \mathrm{~g} / 100 \mathrm{~g})$ which, moreover, were characterised by high soluble solids content $(14.7 \%)$. The acid content depends on the cultivation method and can be between 0.83 and 1.78/100 g (Hecke et al. 2006). The cultivar with the lowest soluble solids content $(12.3 \%)$ and sugars $(8.59 \mathrm{~g})$ is Altlander Pfannkuchenapfel. This cultivar contains significantly less fructose $(3.96 \mathrm{~g})$, relatively little glucose $(2.22 \mathrm{~g})$, and a large amount of sucrose $(2.41 \mathrm{~g})$.

Due to the health-promoting properties of individual sugars, it is worth distinguishing those cultivars whose fruits contain the highest percentage of glucose and the lowest percentage of other sugars (Figure 1). The sweetest cultivars are Kaiser Wilhelm, Winter Goldparmane, and Landsberger Renette. However, in these three cultivars, the glucose content is the lowest in percentage terms. In terms of sugar quality, the best cultivars are Weisser Winterkslvill, Oberlander Himbeerapfel, and Altlander Pfannkuchenapfel. The sugar to acid proportion is worth attention. The lower the value the better. Among the studied cultivars, Altlander Pfannkuchenapfel (9.4) and Horneburger Pfannkuchenapfel (9.5) were characterised by the lowest value of this index. The cultivars Oberlander
Himbeerapfel (35.7) and Kaiser Wilhelm (20.3) have an unfavourable index value. The consumer feels that the fruit is very sweet, bland/insipid. The values of the other cultivars are between 10 and 12 , which is a very good result compared to the leading breeding cultivars. In comparison with apples currently grown on a mass scale, the tested cultivars are very favourable. The most important for the industry indicator of sugar to acid ratio is in the case of some of the studied apple cultivars more than twice lower than in the case of commonly bred cultivars (Petkovsek et al., 2007: Nicolae et al., 2008). This proportion is important because of the sugar excess in the fruit compared to the acids. Perhaps the use of older cultivars would optimise the production processes of some preserves and avoid some problems associated with the excessive fruit sweetness.

Pectins have a health-promoting effect on humans and naturally occur in fruits. Apples are in the group with the highest pectin content, which increases their nutritional value (Waszkiewicz-Robak, 2005). The fruits of Horneburger Pfannkuchenapfel cultivar were characterised by the highest content of pectins $(1.68 \mathrm{~g} / 100 \mathrm{~g})$ and the smallest one by Oberlander Himbeerapfel $(0.71 \mathrm{~g} / 100 \mathrm{~g})$ (Table 3). Nitrates and nitrites effect negatively on human health, their excess may lead to various diseases (Grudzińska and Zagórska, 2005; Wojciechowska, 2005), however, it should be stressed that all the cultivars studied had very low levels of harmful nitrates and nitrites. They meet very strict standards for products for children - $<200 \mathrm{mg} / 1000 \mathrm{~g}$ (European Commission Regulation 1881/2006, 2006). The nitrate content was in the range 24.5$52.0 \mathrm{mg} / 1000 \mathrm{~g}$ and nitrite $0.10-0.26 \mathrm{mg} / 100 \mathrm{~g}$. These are values similar to other fruits (Kruczek et al., 2020, Ochmian et al., 2019) or parasites used in the food industry (Piwowarczyk et al., 2020 a,b).

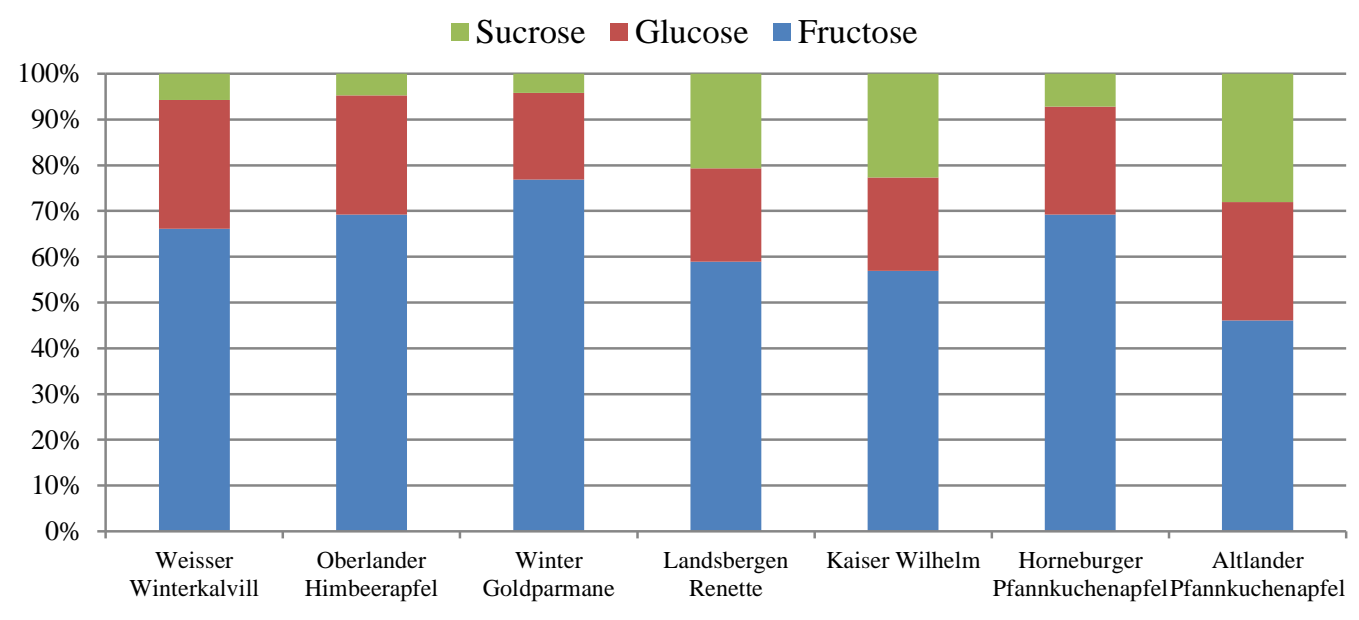

Figure 1. Percentage of sugars in the fruits tested 
Table 3. Pectin, nitrate, nitrite and $\mathrm{pH}$ content of the fruits tested

\begin{tabular}{lllll}
\hline & $\mathrm{pH}$ & Pectines $(\mathrm{g} / 100 \mathrm{~g})$ & Nitrite - NO3 $(\mathrm{mg} / 1000 \mathrm{~g})$ & Nitrite $-\mathrm{NO} 2(\mathrm{mg} / 1000 \mathrm{~g})$ \\
\hline Weisser Winterkalvill & $3.42 \mathrm{~b}$ & $1.01 \mathrm{c}$ & $24.5 \mathrm{a}$ & $0.15 \mathrm{bc}$ \\
Oberlander Himbeerapfel & $4.60 \mathrm{~d}$ & $0.71 \mathrm{a}$ & $44.5 \mathrm{c}$ & $0.19 \mathrm{~d}$ \\
Winter Goldparmane & $3.35 \mathrm{ab}$ & $1.19 \mathrm{~d}$ & $35.9 \mathrm{bc}$ & $0.12 \mathrm{ab}$ \\
Landsberger Renette & $3.23 \mathrm{a}$ & $1.27 \mathrm{~d}$ & $36.2 \mathrm{bc}$ & $0.15 \mathrm{bc}$ \\
Kaiser Wilhelm & $3.87 \mathrm{c}$ & $0.89 \mathrm{~b}$ & $29.8 \mathrm{ab}$ & $0.17 \mathrm{~cd}$ \\
Horneburger Pfannkuchenapfel & $3.31 \mathrm{ab}$ & $1.68 \mathrm{e}$ & $29.9 \mathrm{ab}$ & $0.10 \mathrm{a}$ \\
Altlander Pfannkuchenapfel & $3.36 \mathrm{ab}$ & $1.20 \mathrm{~d}$ & $52.0 \mathrm{~d}$ & $0.26 \mathrm{e}$ \\
\hline
\end{tabular}

\section{Fruit quality after freeze-drying}

The drying process reduces water activity in the product, slows down enzymatic reactions, and sometimes reduces the number of microorganisms. During drying, the product weight and volume are also reduced, which reduces packaging, transport, and storage costs. Adequate humidity of dried fruits also guarantees their long storage. Preliminary research has shown that fruits which obtained moisture content of $18 \%$ did not have a satisfactory appearance - they were not fragile. Similar observations were found during the drying of highbush blueberry fruits (Ochmian et al., 2020). In the next stage, the fruit was dried to $10 \%$ humidity. However, removing water from the fruit to a very low level of 2-3\% is not justified. This prolongs the freeze-drying process, which adversely affects the aroma of dried fruit (Fox et al. 2004). It also results in higher energy consumption. In the case of fruit, the humidity should be between 18 and $23 \%$, and for vegetables - from 8 to $12 \%$. Polish standards for dried apple provide for humidity $<20 \%$ (PN-A77608). This enables long-term storage of the dry in ordinary conditions (Gyurova, \& Enikova, 2014). During drying, changes occur in the structure, chemical composition, and colour of the fruit. Studies by other authors have shown that freezedried apples were less darkened and had the highest organoleptic rating, compared to other drying methods (Wichrowska et al., 2016). Consumers believe that the lighter colour of dried fruit is a sign of high palatability of products compared to darker ones (Pękosławska-Garstka \& Lenart, 2010). Therefore, to avoid additional fruit processing, e.g. blanching, fruit that will be resistant to these unfavourable changes are sought. Colour is a good indicator with which we can assess the condition of the plants and fruit (Antal et al., 2013). Among the tested cultivars, the darkest (determined by the $L^{*}$ parameter) fruit - skin, fresh flesh, and after freezedrying was characterised by Oberlander Himbeerapfel cultivar (Figure 2). The other cultivars had a similar flesh colour. The brightest skin and flesh had the Horneburger Pfannkuchenapfel cultivar. These fruits were also characterised by the smallest change in the colour of freeze-dried flesh compared to fresh flesh. These values were comparable to those of Elstar $\left(L^{*} 91.3\right)$ and much higher compared to Ligol ( $\left.L^{*} 77.6\right)$ (Wichrowska et al., 2016). The tested cultivars also differed in chromatic parameters of colour $a^{*}$ and $b^{*}$.

The highest parameters $b^{*}$ had the fruit of Oberlander Himbeerapfel cultivar (Figure 3). Drying caused the colour of the flesh to be even more intense, in the yellow-orange direction, while the value of the parameter $a^{*}$ remained at a similar level. Fresh flesh of the remaining cultivars had similar values of parameter $a^{*}$, from -0.4 to 1.5 . After drying, the flesh of these cultivars changed slightly in colour, which is evidenced by the increase in parameters $a^{*}$ and $b^{*}$.

\section{Polyphenolic compounds}

Phenolic compounds affect the quality of fruit: taste, colour, health-promoting properties (antiinflammatory, anti-allergenic, antidiabetic, antifungal, antiviral, and chemo-protective) (Sato et al., 2011; Hernández-Alcántar's et al., 2016). In both fresh and freeze-dried fruits the content of polyphenols classified into particular groups was as follows: phenolic acids > flavano-3-ols $>$ flavonols $>$ anthocyanins (Figure 4 and Figure 5). A similar relationship was found by Oszmianski et al. (2018). A large share of phenolic acids in apples was also written by Wojdyło et al. (2008) and Veberic et al. (2005). Chlorogenic acid, as one of the main phenolic acids, is mainly responsible for the taste of fruit, but it also has health-promoting properties: antimutagenic and antioxidant. During the drying process, the content of polyphenolic compounds increased on average 4.9 times. Comparing this with the dry matter of these fruits, it could be expected that the polyphenol content in dried fruits should be higher. Thus, it shows the degradation of polyphenols during drying. Freeze-drying allows for better preservation of nutritional values, including polyphenols and aroma, colouring compared to fruits dried traditionally (Ciurzyńska and Lenart 2010a, Rutkowska et al. 2012). 


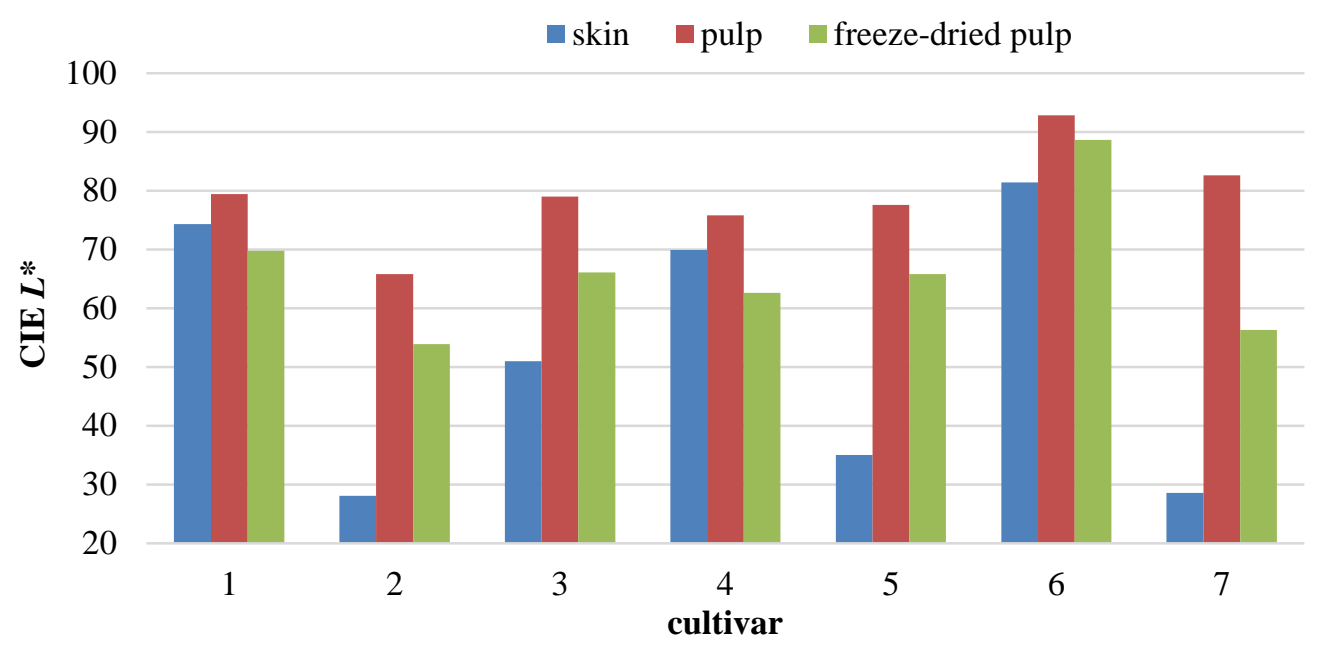

Figure 2. Changes in colour parameters $L^{*}$ after a freeze-drying period.

1 - Weisser Winterkalvill; 2- Oberlander Himbeerapfel; 3 - Winter Goldparmane - Golden Reinette; 4 - Landsberger

Renette; 5 - Kaiser Wilhelm; 6 - Horneburger Pfannkuchenapfel; 7 - Altlander Pfannkuchenapfel

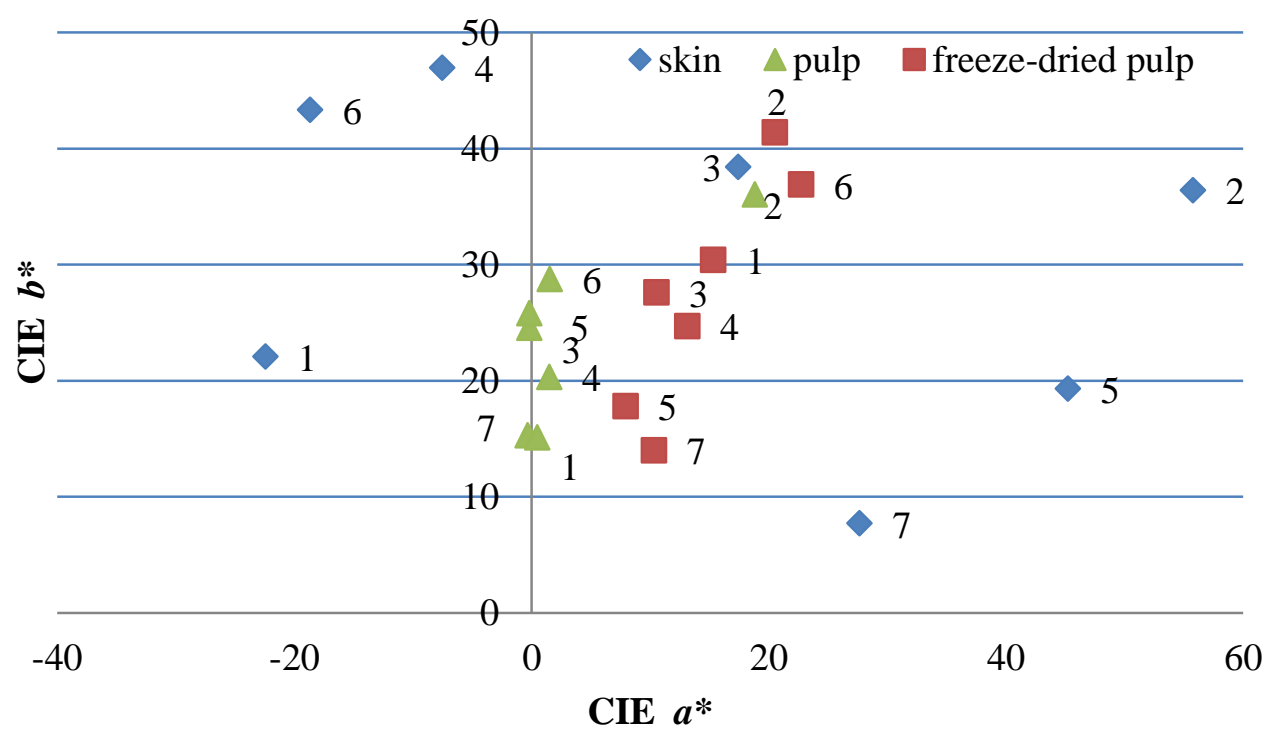

Figure 3. Changes in colour parameters of fruit flesh after freeze-drying

Chokeberry fruit dried by air had 8 times lower content of anthocyanins in comparison with freezedried fruit (Bober and Oszmiański 2004). Freezedried fruit also had a higher anthocyanin content compared with fruit dried conventionally with warm air (Bustos et al., 2018). However, these authors claim that drying berries at medium temperatures resulted in the fruit retaining a significant proportion of anthocyanins, and this process was much more cost-effective than in the case of freeze-drying.

The highest content of polyphenolic compounds was found in fruits of Winter Goldparmane cultivar (fresh $354 \mathrm{mg}$ : dried $1486 \mathrm{mg}$ ). The drying process had a positive effect on the maintenance of both phenolic acids and flavan-3-ols. The fruit of Oberlander Himbeerapfel was characterised by a high content of anthocyanins. The high content of these compounds is also confirmed by high parameters of colour $a^{*}$ and $b^{*}$ (Fig. 3). Fresh Weisser Winterkalvill fruits, despite their similar polyphenol content to other cultivars, were characterised by the lowest amount after freezedrying. Compared to other cultivars, there was significant degradation of phenolic acids. 


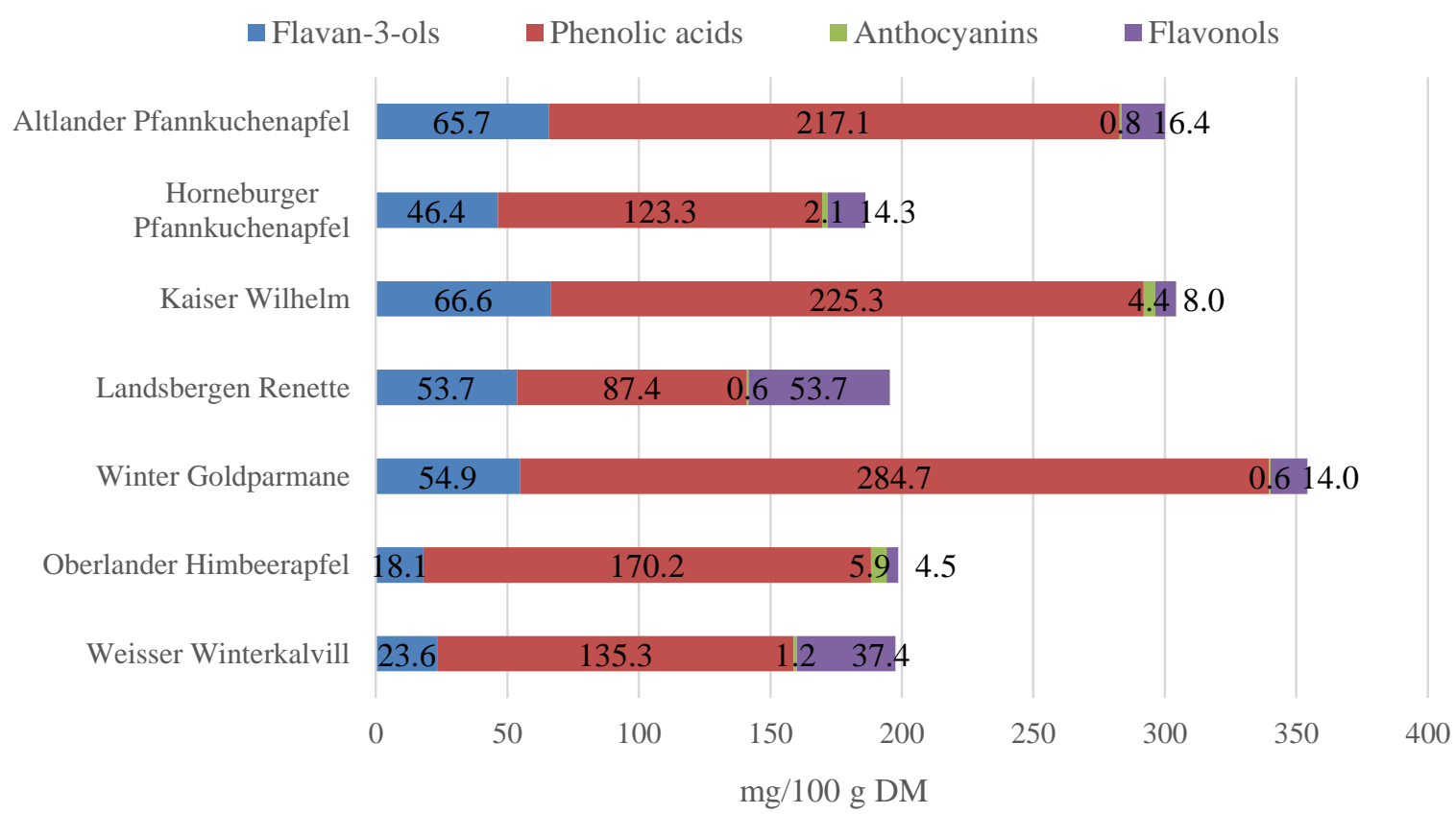

Figure 4. The content of polyphenolic compounds $(\mathrm{mg} / 100 \mathrm{~g} \mathrm{dm})$ in fresh fruit of old apple cultivars

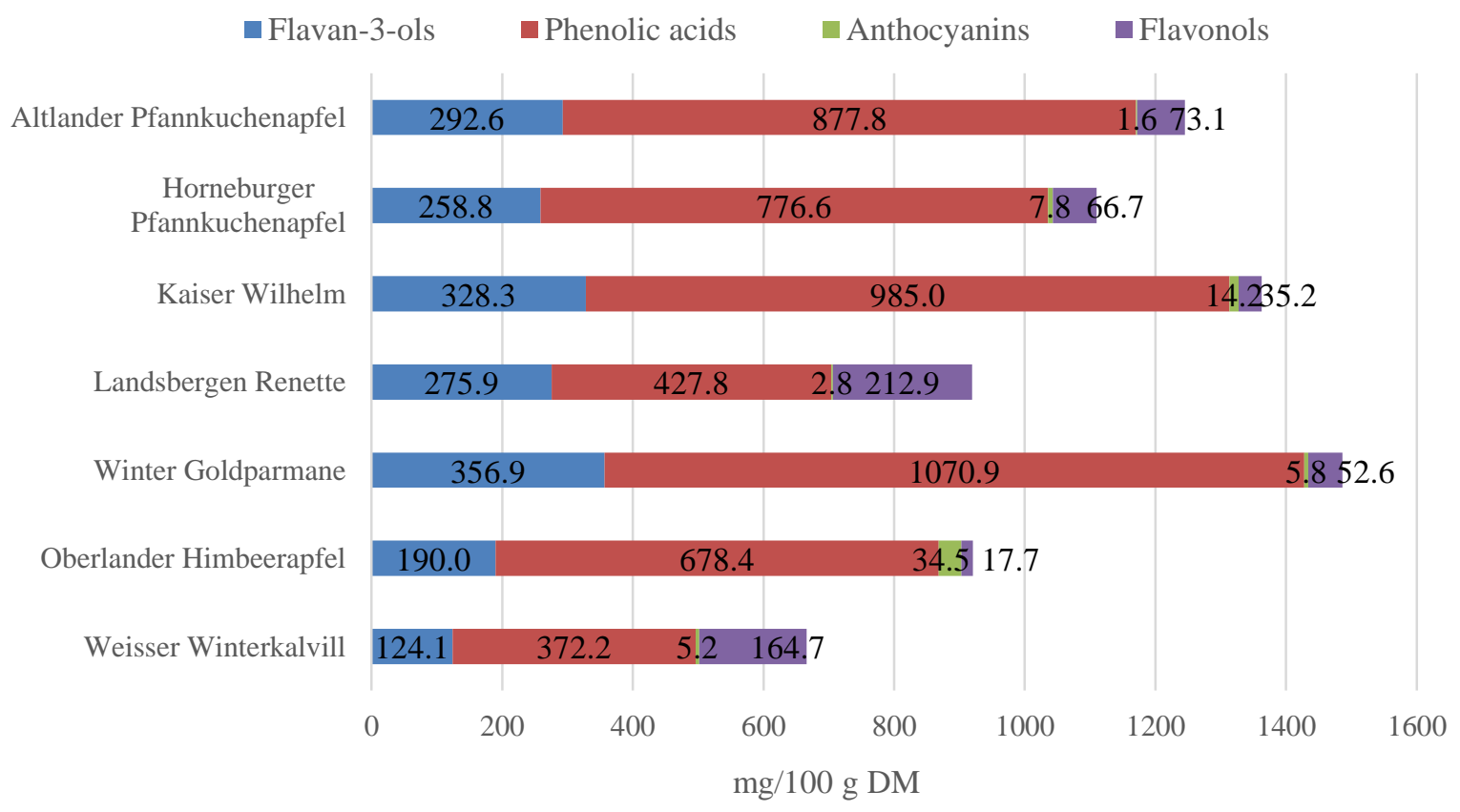

Figure 5. The content of polyphenolic compounds $(\mathrm{mg} / 100 \mathrm{~g} \mathrm{dm})$ in dried fruit of old apple cultivars

\section{CONCLUSIONS}

Even though pesticides have not been used for many years, all the tested trees were fruitful and the damage caused by pests or symptoms of the disease was minor or absent (Altlander Pfannkuchenapfel). The largest fruits were Landsberger Renette and Winter Goldparmane.

The fruit was characterised by a similar soluble extract content (14.4-16.4\%) but a very different amount of organic acids (0.27-1.07). The low acid content in Oberlander Himbeerapfel cultivar resulted in a very high sugar/acid ratio - 35.7, unfavourable for processing. In all cultivars studied the dominant sugar was fructose.

They were also characterised by a very low content of harmful NO3 and NO2. The polyphenols content in 7 fresh apples studied ranged from $186 \mathrm{mg}$ 
(Horneburger Pfannkuchenapfel) to $354 \mathrm{mg} / 100 \mathrm{~g}$ (Winter Goldparmane) and increased after freezedrying from $666 \mathrm{mg}$ (Weisser Winterkalvill) to $1486 \mathrm{mg}$ (Winter Goldparmane). The increase of polyphenols content in freeze-dried fruits was 4.9 times on average. The dominant group of compounds was phenolic acid. All cultivars were characterised by very low anthocyanins content.
The brightest skin and fresh, freeze-dried flesh were characteristic for Horneburger Pfannkuchenapfel. Oberlander Himbeerapfel fruits were the darkest, and the freeze-drying process caused adverse changes in colour, making them even less attractive to consumers.

\section{Funding}

The research was carried out with the participation of the Woliński National Park and was financed from the forest fund provided by the National Forests.

\section{Conflict of interest}

The authors declare that they have no known competing financial interests or personal relationships that could have appeared to influence the work reported in this paper.

\section{Compliance with ethics requirements}

This article does not contain any studies with human or animal subjects.

\section{REFERENCES}

1. Antal, T., Sikolya, L., \& Kerekes, B. (2013). Assessment of freezing pre-treatments for the freeze dried of apple slices. Acta Univ. Cibiniensis, Ser. E: Food Technol. 17(2), 3-14. DOI: 10.2478/aucft-20130006.

2. Bober I., \& Oszmiański J. (2004). Zastosowanie wytłoków aronii do naparów herbat owocowych. Acta Sci.Pol., Technol. Aliment. 3(1), 63-72.

3. Bustos, M. C., Rocha-Parra, D., Sampedro, I., de Pascual-Teresa, S., \& León, A. E. (2018). The influence of different air-drying conditions on bioactive compounds and antioxidant activity of berries. J. Agric. Food Chem., 66(11), 2714-2723. DOI: https://doi.org/10.1021/acs.jafc.7b05395.

4. Chełpiński, P., Ochmian, I., \& Forczmański, P. (2019). Sweet Cherry Skin Colour Measurement as an Non-Destructive Indicator of Fruit Maturity. Acta Univ. Cibiniensis, Ser. E: Food Technol., 23(2), 157166. DOI: https://doi.org/10.2478/aucft-2019-0019.

5. Ciesa, F., Höller, I., Guerra, W., Berger, J., Dalla Via, J., \& Oberhuber, M. (2015). Chemodiversity in the Fingerprint Analysis of Volatile Organic Compounds (VOCs) of 35 Old and 7 Modern Apple Cultivars Determined by Proton-Transfer-Reaction Mass Spectrometry (PTR-MS) in Two Different Seasons. Chem. Biodivers., 12(5), 800-812. DOI: 10.1002/cbdv.201400384.

6. Ciurzyńska A., Lenart A., (2010). Rehydration and sorption properties of osmotically pretreated freezedried strawberries. J. Food Eng., 97(2), 267-274. DOI: 10.1016/j.jfoodeng.2009.10.022.

7. Czyżowski, P., Drozd, L., Gruszecki, T. M., \& Tajchman, K. (2017). Rola gospodarki łowieckiej w kształtowaniu bioróżnorodności. Wiad. Zootechn., 55(5), 198-202.

8. Donno, D., Beccaro, G. L., Mellano, M. G., Torello Marinoni, D., Cerutti, A. K., Canterino, S., \& Bounous, G. (2012). Application of sensory, nutraceutical and genetic techniques to create a quality profile of ancient apple cultivars. J. Food Qual., 35(3), 169-181. DOI: 10.1111/j.17454557.2012.00442.x.

9. European Commission. (2006). Commission Regulation (EC) No 1881/2006 of 19 December 2006 setting maximum levels for certain contaminants in foodstuffs. Off. J. Eur. Union, 364(365-324).

10. Grudzińska, M., \& Zgórska, K. (2005). Wpływ obróbki wstępnej oraz metod gotowania na zawartość azotanów w warzywach. Rocz. Ochr. Sr., 7, 233-41.

11. Gyurova, D., \& Enikova, R. (2014). Dried fruits-brief characteristics of their nutritional values. Author's own data for dietary fibers content. Pol. J. Food Nutr. Sci., 2(4), 105-109. DOI: 10.11648/j.jfns.20140204.12.

12. Haze, M. (2012). Zasady hodowli lasu. Warsaw: Centrum Informacyjne Lasów Państwowych.

13. Hecke, K., Herbinger, K., Veberič, R., Trobec, M., Toplak, H., Štampar, F., ... \& Grill, D. (2006). Sugar, acid-and phenol contents in apple cultivars from organic and integrated fruit cultivation. Eur. J. Clin. Nutr, 60(9), 1136-1140. 
14. Hernández-Alcántara, A. M., Totosaus, A., \& Pérez-Chabela, M. L. (2016). Evaluation of agro-industrial co-products as source of bioactive compounds: fiber, antioxidants and prebiotic. Acta Univ. Cibiniensis, Ser. E: Food Technol., 20(2), 3-16. DOI: 10.1515/aucft-2016-0011.

15. Janowicz, M., Kowalska, H., Lenart, A. (2012). Przyszłość przekąsek owocowych i warzywnych. Przemysł Fermentacyjny i Owocowo-Warzywny, 2(56), 9-11.

16. Kellerhals, M., Szalatnay, D., Hunziker, K., Duffy, B., Nybom, H., Ahmadi-Afzadi, M., ... \& Lateur, M. (2012). European pome fruit genetic resources evaluated for disease resistance. Trees, 26(1), 179-189. DOI 10.1007/s00468-011-0660-9.

17. Konopacka, D., Płocharski, W. (2003). Dietetyczne chrupki z owoców i warzyw -atrakcyjne formy kruchego suszu przeznaczonego do bezpośredniej konsumpcji. Acta Agrophysica, 2(3), 567-577.

18. Kruczek, A., Ochmian, I., Krupa-Małkiewicz, M., \& Lachowicz, S. (2020). Comparison of Morphological, Antidiabetic and Antioxidant Properties of Goji Fruits. Acta Univ. Cibiniensis, Ser. E: Food Technol, 24(1), 1-14. 10.2478/aucft-2020-0001

19. Le Bourvellec, C., Bouzerzour, K., Ginies, C., Regis, S., Plé, Y., \& Renard, C. M. (2011). Phenolic and polysaccharidic composition of applesauce is close to that of apple flesh. J. Food Compos. Anal., 24(45), 537-547. https://doi.org/10.1016/j.jfca.2010.12.012.

20. Mijowska, K., Ochmian, I., \& Oszmiański, J. (2016). Impact of cluster zone leaf removal on grapes cv. Regent polyphenol content by the UPLC-PDA/MS method. Molecules, 21(12), 1688. DOI: 10.3390/molecules21121688.

21. Mohanty, S., Ray, P., Swain, M. R., \& Ray, R. C. (2006). Fermentation of cashew (Anacardium occidentale L.)"apple" into wine. J. Food Process. Pres., 30(3), 314-322. DOI: 10.1111/j.17454549.2006.00067.x.

22. Nicolae, S., Paul-Bădescu, A., Nicola, C., \& Pârvan, C. (2008). Chemical and biochemical components in fruit and their role in the human health. Scientific Papers of the Research Institute for Fruit Growing Pitesti, Romania, 24, 138-143.

23. Ochmian, I. (2007). The influence of irrigation and fertilisation on growth and yielding of three cultivars of apple trees on semi-dwarfing rootstocks. Folia Universitatis Agriculturae Stetinensis. Agricultura, Alimentaria, Piscaria et Zootechnica, 3(3), 135-142.

24. Ochmian, I., Oszmiański, J., Lachowicz, S., \& Krupa-Małkiewicz, M. (2019). Rootstock effect on physico-chemical properties and content of bioactive compounds of four cultivars Cornelian cherry fruits. Sci. Hortic. 256, 108588. https://doi.org/10.1016/j.scienta.2019.108588

25. Ochmian, I., Figiel-Kroczyńska, M., \& Lachowicz, S. (2020). The Quality of Freeze-Dried and Rehydrated Blueberries Depending on their Size and Preparation for Freeze-Drying. Acta Univ. Cibiniensis, Ser. E: Food Technol. 24(1), 61-78. 10.2478/aucft-2020-0006

26. Oszmiański, J., Lachowicz, S., Gławdel, E., Cebulak, T., \& Ochmian, I. (2018). Determination of phytochemical composition and antioxidant capacity of 22 old apple cultivars grown in Poland. Eur. Food Res. Technol. 244(4), 647-662. DOI: 10.1007/s00217-017-2989-9.

27. Page, K. A., Chan, O., Arora, J., Belfort-DeAguiar, R., Dzuira, J., Roehmholdt, B., ... \& Sherwin, R. S. (2013). Effects of fructose vs glucose on regional cerebral blood flow in brain regions involved with appetite and reward pathways. Jama, 309(1), 63-70. doi:10.1001/jama.2012.116975.

28. Pękosławska-Garstka, A., \& Lenart, A. (2010). Some physical properties of pumpkin tissue osmotically dehydrated in sugar solutions. Acta Agrophysica, 16(2), 413-422.

29. Petkovsek, M. M., Stampar, F., \& Veberic, R. (2007). Parameters of inner quality of the apple scab resistant and susceptible apple cultivars (Malus domestica Borkh.). Sci. Hortic., 114(1), 37-44. https://doi.org/10.1016/j.scienta.2007.05.004.

30. Pijanowski, E., Mrożewski, S., Horubała, A. \& Jarczyk, A. Technologia produktów owocowych i warzywnych, tom I. PWRiL, Warszawa. (1973).

31. Piwowarczyk, R., Ochmian, I., Lachowicz, S., Kapusta, I., \& Sotek, Z. (2020 a). Phytochemical and Bioactive Properties of Phelypaea Tournefortii-Effect of Parasitic Lifestyle and Environmental Factors. Acta Univ. Cibiniensis, Ser. E: Food Technol. 24(1), 113-128. 10.2478/aucft-2020-0010.

32. Piwowarczyk, R., Ochmian, I., Lachowicz, S., Kapusta, I., Sotek, Z., \& Błaszak, M. (2020 b). Phytochemical parasite-host relations and interactions: A Cistanche armena case study. Sci. Total Environ, 716, 137071. https://doi.org/10.1016/j.scitotenv.2020.137071

33. PN-90/A-75101/03. Przetwory owocowe i warzywne - Przygotowanie próbek i metody badań fizykochemicznych - Oznaczanie zawartości suchej masy metodą wagową. 
34. PN-90/A-75101/04. Przetwory owocowe i warzywne. Przygotowanie próbek i metody badań fizykochemicznych. Oznaczanie kwasowości ogólnej.

35. PN-90/A-75101/07. Przetwory owocowe i warzywne. Przygotowanie próbek i metody badań fizykochemicznych. Oznaczanie zawartości cukrów i ekstraktu bezcukrowego.

36. PN-A-77608. 1997. Produkty owocowe. Jabłka, gruszki, wiśnie suszone. Polski Komitet Normalizacyjny. Warszawa: 1-11.

37. Poznański G. Stare sady owocowe i tradycyjne ogrody wiejskie na terenie Pogórza Przemyskiego dziedzictwem kulturowo-przyrodniczym. Wydawnictwo Epograf, (2014).

38. Rutkowska, J., Adamska, A., Pielat, M., \& Bialek, M. (2012). Porównanie składu i właściwości owoców dzikiej róży (Rosa rugosa) utrwalanych metodami liofilizacji i suszenia konwencjonalnego. Zywn-Nauk. Technol. Ja. 19(4).

39. Sato, Y., Itagaki, S., Kurokawa, T., Ogura, J., Kobayashi, M., Hirano, T., ... \& Iseki, K. (2011). In vitro and in vivo antioxidant properties of chlorogenic acid and caffeic acid. Int. J. Pharm., 403(1-2), 136-138. DOI: 10.1016/j.ijpharm.2010.09.035.

40. Tetera, V. (2003). Zachrana starych a krajovych odrud ovocnych drevin.

41. Van Treuren, R., Kemp, H., Ernsting, G., Jongejans, B., Houtman, H., \& Visser, L. (2010). Microsatellite genotyping of apple (Malus $\times$ domestica Borkh.) genetic resources in the Netherlands: application in collection management and variety identification. Genetic Resources and Crop Evolution, 57(6), 853-865.

42. Veberic, R., Trobec, M., Herbinger, K., Hofer, M., Grill, D., \& Stampar, F. (2005). Phenolic compounds in some apple (Malus domestica Borkh) cultivars of organic and integrated production. J. Sci. Food Agric., 85(10), 1687-1694. DOI:10.1002/jsfa.2113.

43. Waszkiewicz-Robak, B. (2005). Pektyny i ich zastosowanie w przemyśle spożywczym. Agro Przemysł, 4, 25-27.

44. Wichrowska, D., Gościnna, K., Knapowski, T., \& Kozera, W. (2016). Impact of drying method in colour of slices of chosen apple varieties. Rola Procesów Technologicznych W Kształtowaniu Jakości Żywności, 23-32.

45. Wojciechowska, R. (2005). Akumulacja azotanów a jakość produktów ogrodniczych. Wyd. Coperite, Kraków, 21-27.

46. Wojdyło, A., Oszmiański, J., \& Laskowski, P. (2008). Polyphenolic compounds and antioxidant activity of new and old apple varieties. J. Agric. Food Chem., 56(15), 6520-6530.

47. Wypych, A., Sulikowska, A., Ustrnul, Z., \& Czekierda, D. (2017). Variability of growing degree days in Poland in response to ongoing climate changes in Europe. Int. J. Biometeorol., 61(1), 49-59. DOI 10.1007/s00484-016-1190-3. 